\title{
Különleges elöretekintési feladatok az utak világában
}

\begin{abstract}
A müszaki szakágak közül jelenleg talán a közúti közlekedési alágazat áll a legintenzívebb és legbonyolultabb kapcsolatban a társadalmi, a müszaki-gazdasági és a természeti környezetével. A kapcsolatrendszer egyes láncszemeinek azonban nagyon eltérő az erőssége, kidolgozottsága és hasznossága, ezért hatalmasak a feladatok és lehetőségek e téren. A világ gyors változása is arra int, hogy időnként újra kell fogalmazni az utak világának viszonyát a sok-összetevős környezetével.
\end{abstract}

DOI 10.24228/KTSZ.2019.2.2

\section{Somfai András - Gaál Bertalan}

ny. okl. szakmérnök és szaküzemgazdász - Széchenyi István Egyetem Közlekedési Tanszék e-mail: somfai.andras@gmail.com - e-mail: gaalb@sze.hu

\section{BEVEZETÉS}

A társadalmi-gazdasági rendszerváltás óta nagy lendületet vett a magyar útépítés. A $32000 \mathrm{~km}$-es országos úthálózaton elkészült $1100 \mathrm{~km}$ gyorsforgalmi út, több száz $\mathrm{km}$ föútkorszerüsítés és elkerülő szakasz, de már egyes forgalmasabb mellékutak is bekerültek a felújítási programba. Az önkormányzatok is építik az útjaikat: voltak évek, amikor több mint $500 \mathrm{~km}$ helyi út épült ki.

Bár a mintegy 32000 km országos közutat tekintve ezek figyelemre méltó mennyiségek, a kb. 210000 km körüli össz-úthosszhoz viszonyítva bizony csak szerények, mégis valamiféle elmozdulást jelentenek a korábbi állapotoktól. Kérdés azonban, hogy adnak-e ezek elegendő adatot hosszú távú következtetések levonásához? Közvetlenül nem, de a fejlődési elemek megváltozása arra ösztönöz, hogy elemezzük $a$ folyamatot, helyezzük azokat tágabb összefüggésekbe és csak utána próbáljunk következtetéseket levonni.
Újabb tényezők felmerülésére - különösen a külsőkre - egyébként is sok esélyünk van, hiszen a müszaki szakágak közül jelenleg talán a közúti közlekedésnek van a legbonyolultabb kapcsolata a hazai társadalmi, müszaki-gazdasági és a természeti környezettel, de a külfölddel is. Mivel ezek a szakterületek maguk is folyamatos átalakulásban vannak, szakmai jövőképünk részleteit indokolt időről-időre felülvizsgálni. Tekintettel a mozgásban levő világra, a jövőképeknek egy sok ágon bonyolódó, permanens, kölcsönös finomítási folyamatára lehet számítani.

Mivel lehetne ezt a „párbeszédet” szakmánk oldaláról segíteni, teljesebbé tenni?

\section{A TÉmATÁr}

Segíthetnénk egy olyan mátrix-rendszerszerü tématár megalkotásával, amelyikbe beleilleszthetők az eddig feldolgozott kapcsolati témák, és amelynek üresen maradt rubrikái ösztönöznének bennünket újabb fel- 


\section{Közúti közlekedés}

adatok megfogalmazására. Ehhez állítsunk össze egy hat-dimenziós, virtuális mátrixot, amelynek élein

1. a szorosabb értelemben vett út-szakma,

2. a müszaki-gazdasági környezet,

3. a társadalmi tényezők,

4. a természeti környezet,

5. az idő és

6. a topográfiai hely legyen.

E mátrixrendszer valamennyi csomópontjában elvileg megjelenő 6-6 adat adja az első kutatási-vizsgálati feladatszintet, úm. a csomópontok szétválogatását három részre:

1. amelyekben ráismerünk egy-egy megoldott problémára,

2. amelyek valódi új feladatot jelentenek, végül

3. amelyekböl nem állítható össze még egy értelmes mondat sem.

\section{Kissé részletesebben:}

- az út-szakmai lista tartalmazza a burkolatok, mütárgyak, előírások, módszerek stb. részletes rendszerét,

- a tágabb müszaki-gazdasági környezet az építtetői, tervezési, kivitelezési feladatokat, eszközöket és lehetőségeket, a közműveket és a belterületi épített környezetet kellene, hogy részletezze,

- a társadalmi környezet a polgároknak az utakkal, ill. a közúti közlekedéssel kapcsolatos általános hozzáállását, ill. egy-egy konkrét útépítéshez, közterület-fejlesztéshez való egyedi viszonyát taglalja,

- a természeti környezet a táji, topográfiai, környezetvédelmi, éghajlati, mezőgazdasági viszonyokat foglalja magában, szintén általánosságban, ill. egyedileg.

Különleges feladat az idő és a tér mátrix-elemeinek meghatározása:

- az idot a „csomópontonkénti” tartalom függvényében kell időtartamként vagy időpontként meghatározni, ezzel is mintegy jelezve, hogy a tényezők nem örökérvényűek. (Mást jelentett pl. 1850-ben a kiépített út és mást jelent ma.)

- a tér - vagy hely - ennél annyiban egyszerübb, hogy felállítható egy teljes körü lista a „világ” léptékétől az egyes kontinenseken, országokon át a kisebb területegységekig. A sok százezer településböl csak a csoportokat és a magyar szakirodalomban legtöbbször szereplö néhány száz települést indokolt a lajstromba felvenni, a listát pedig célszerü nyitottan hagyni. A „hely” természetesen egy-egy építési helyszínt is jelenthet.

Mivel a csomópontok száma óriási lesz, a szétválogatását egy nagy türelmü, komplex tudományos vizsgálóbizottságra kellene bízni. Így a „szakmán túli”, külső környezet felől közelítve olyan különleges és meglepő új kutatnivalók is körvonalazódhatnak majd, amelyeket „belülről” nézve (ma még) nem veszünk észre.

A tématár - nevezhetjük akár Kutatási Kincstárnak is - elősegíthetné a szakmai-szakmaközi párbeszédet is. A „más” szakmák számára ez lenne a legnagyobb haszna, de elősegítené saját szakmánk komplexebb látásmódját is.

A gyakorlati részleteket még ki kell dolgozni, és számos felmerülö kérdést széleskörüen is meg kell vitatni. Már csak azért is, mert az „utak világa” nem egy pontosan lehatárolható fogalom, csak azért választottuk, hogy a módszer-javaslatot egy viszonylag kisebb problémakörön belül be lehessen mutatni. Természetesen a kutatás során hatnál több mátrix-elem szükségessége is felmerülhet. A „müszaki-gazdasági” környezet listáját is lehet, hogy mégis csak szét kell választani - ez majd kialakul. A javaslat némiképp a Delphi módszer továbbfejlesztésének is tekinthető.

\section{HÁROM PÉLDA A TÉMATÁR HASZNÁLATÁRA}

A tématár használata és hasznossága a legmeggyőzőbben a gyakorlatban mutatható be. Kiválasztunk az út-szakma körében felsorolt tárgy, módszer vagy fogalom közül egyet, és kezdünk tallózni a többi három szakmai listában, plusz az idő és tér keresőben. A bemutató 


\section{Közúti közlekedés}

okán célirányos kiválasztással haladunk, hogy minél több kutatni-vizsgálni valót tudjunk bemutatni és felkelteni a kedvet a hasonló tallózásokra, egy-egy probléma ízekre szedésére. Ezt tudományos vizsgálóbizottság nélkül és helyett magunk is megtehetjük. A kiválasztott három téma a következő:

1. kiemelt szegély,

2. útkiépítettség,

3. közterület-szabályozás.

A mintapéldákban csak felvetünk néhány problémát, de nem részletezzük. Célunk a gondolatébresztés.

\subsection{Első téma: a kiemelt útszegély}

A kiemelt útszegély az út-szakma egyik leglátványosabb eleme és a burkolatok „zsandárja”. Látszólag egyszerű, kiforrott, bevált termék, amely számos változatban készül. Vizsgáljuk meg, hogy a különböző nézőpontú igényeknek hogyan felel meg a kiemelt szegély?

\subsubsection{Az út-szakmai környezet}

A kiemelt útszegély általában gépjárműforgalmi útburkolat lehatárolását szolgáló betonvagy kőelem. A lehatárolás célja a forgalombiztonság növelése, a csapadékvíz terelése és esztétikai igények kiszolgálása. A háromféle feladat általában keverten és néha ellentmondásosan jelentkezik.

Az útpályafelületek lehatárolása. Ahol nem egyenes a burkolatszél helyszínrajzi és/vagy magassági vonalvezetése, ott a kiemelt szegély segíti a jármünek a burkolatfelületen való pozicionálását. Terelőszigeteknél, útpálya-szétválásoknál a gyalogosok, táblák, lámpaoszlopok védelmét is szolgálja. Vajon nem kellene-e az eltérő céloknak a szegély- és szegély-elhelyezési választékban is megjelenniük?

Forgalmi és baleseti elemzések segíthetnének a korrekt válaszadásban és a tervezési elöírások esetleges finomításában. Már csak azért is, mert a bel- vagy külterületi helyzet, az eltérő helyszín-megközelítési sebesség is igényelhet eltérő pozicionálást vagy pl. a biztonsági sáv elhagyását „K” szegély esetén.
A csapadékvíz terelése. Reagálhatna-e az éghajlatváltozásra a kiemelt szegély is? A nagyobb víztömegre nem kellene-e keresztbordás és/ vagy homorú felületü, süllyesztett szegély futósorral „válaszolnunk”? Mit kellene tenni ahhoz, hogy a folyókával kombinát kiemelt szegélyek jobban terjedjenek? Miért nem harcolnak a kerékpáros szervezetek és az útkezelők az oldalbeömlős víznyelőkért? Tegyünk-e víznyelőt a szélesebb gyalogátkelőhelyek mind a négy sarkára?

Esztétikai kérdések. A szegélyelemek közötti hézag cementhabarcs-kiöntése nem mindegyik szegélyrakónak sikerül szépre (1. ábra). Nem kellene-e valami szaporább és szebb megoldást átvenni vagy kitalálni? Csúnyák a tört szegélyekből kirakott kissugarú ívek vagy a durva törések is (2. ábra). Miért nem építünk be íves szegélyköveket, pedig ilyenek már kaphatók? Miért építünk be újra régi, pattintott élü terméskő kiemelt szegélyeket? Többször meghagyjuk a régit, egy új járda és egy új útburkolat között.

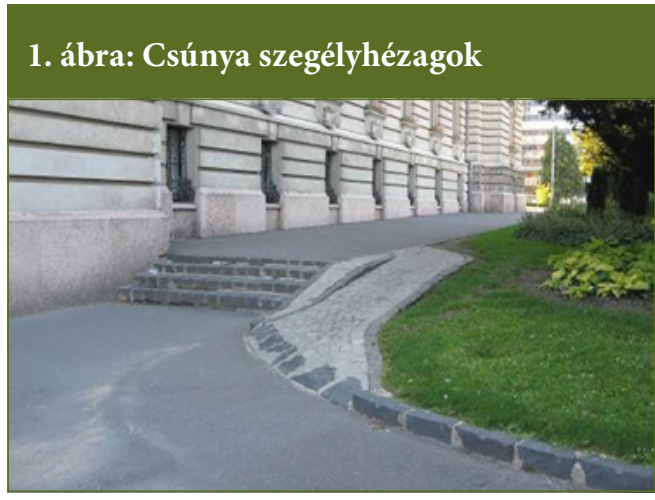

2. ábra: Ide íves szegély illenék

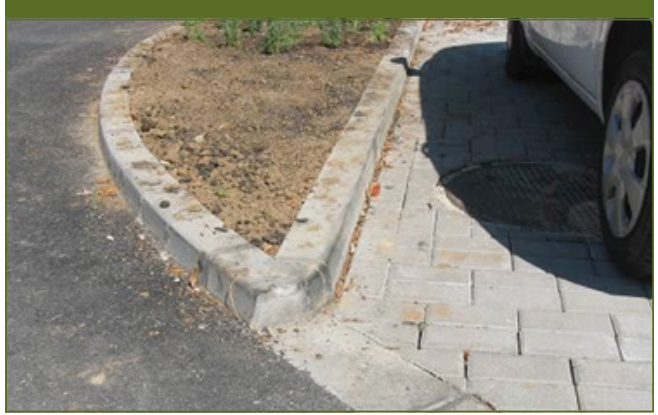




\section{Közúti közlekedés}

\subsubsection{A tágabb müszaki-gazdasági környezet}

Vizsgáljuk meg a Magyarországon kapható kiemelt szegélyek gyártási és beépitési elöírásait, a vállalt élettartammal és a költségekkel együtt, figyelemmel a régebbi beépítésü útszegélyekre (kő, keramit) is. Nézzük meg, hogy egy keskeny zöldsávot határoló két kiemelt szegély között alig marad kapcsolat az altalaj és a zöldsáv földanyaga között, ha a beton támasztógerenda hátsíkja függőlegességét nem tartjuk be - márpedig sokszor nem tartjuk be, és kiszárad a növényzet. Itt bukkan fel egy különleges, hosszú távú müszaki-gazdasági mérlegelnivaló. Amíg ugyanis beépítetlen területen alig van akadálya az utak újabb és újabb aszfalt-rászőnyegezésének, addig belterületen ez 2-3 réteg után általában megakad, ha az újabb szőnyegezésnél „elfogyna” a kiemelt szegély, és bizonytalanná válna a szegély menti vízelvezetés. Ezen az segítene, ha az út kiemelt szegélyét reális költségért meg lehetne emelni. Ám ha az emelés a járda szintjének megemelését is igényli, de ez az emelés - az épületek küszöbszintjei miatt megoldhatatlan, akkor a közlekedési ágazat rákényszerül egy drágább és rövidebb életű részleges vagy teljes burkolatcserére vagy szükségmegoldásokra. Természetesen tudjuk, hogy nem lehet örökké rászőnyegezni, de aki a szőnyegezéssel időt nyer, az kiadást halaszt későbbre. Emiatt ez az előretekintési téma kiemelt figyelmet érdemel mind a mérnöki, mind pedig az építész szakág részéről.

\subsubsection{A társadalmi környezet}

A társadalom több változatban is találkozik a kiemelt szegéllyel.

A kivitelezö szervezet rakodómunkását és a szegélyrakó szakmunkást elsősorban a szegélyépítés gyorsasága érdekli, mert attól függ a pénze. A 25-40-50 cm méretü elemekkel könnyebb bánni, de lassabb velük a munka, az $1 \mathrm{~m}$ hosszú elemek viszont $96 \mathrm{~kg}$-osak is lehetnek, amelyek emelőollós és görnyedve-térdelve történő mozgatása és precíz beállítása már inkább kétemberes feladat, tehát a szaporasági megítélés többtényezős. Ráadásul a felfelé szü- külő alakú szegélyelemen nincs jó fogás - nem lehetne-e valamilyen horonnyal, mélyedéssel, stb. ezen segíteni?

A közlekedők közül a gépjárművezetőt a kiemelt útszegély egyrészt segíti az útvonal szerinti haladásban, másrészt viszont a szegély veszélyezteti az esetleg nekimenő jármü épségét. Mit mutatnak a baleseti elemzések? A szegélymagasság megítélése is változik, mert ma már csak $12 \mathrm{~cm}$ a kiemelt szegély jellemző magassága, és a hídszegély kötelező mérete is lement $20 \mathrm{~cm}$-röl „10-15 cm közötti” méretre. Ennek a csökkenésnek leginkább a kerékpárosok örülhetnek. Van azonban más elgondolkodtató is: a lovas kocsik vasabroncsa „ellen” szóló egykori magas, éles kőszegélyek után hiába kezdett a 70-es években terjedni a $6 \mathrm{~cm}$-es sugárral lekerekített betonszegély, mostanában a lekerekítés $2 \mathrm{~cm}$-re csökkent, ami nem nevezhetö kerékbarát megoldásnak (3-4. ábrák). Hol, melyik megoldásnak van létjogosultsága?
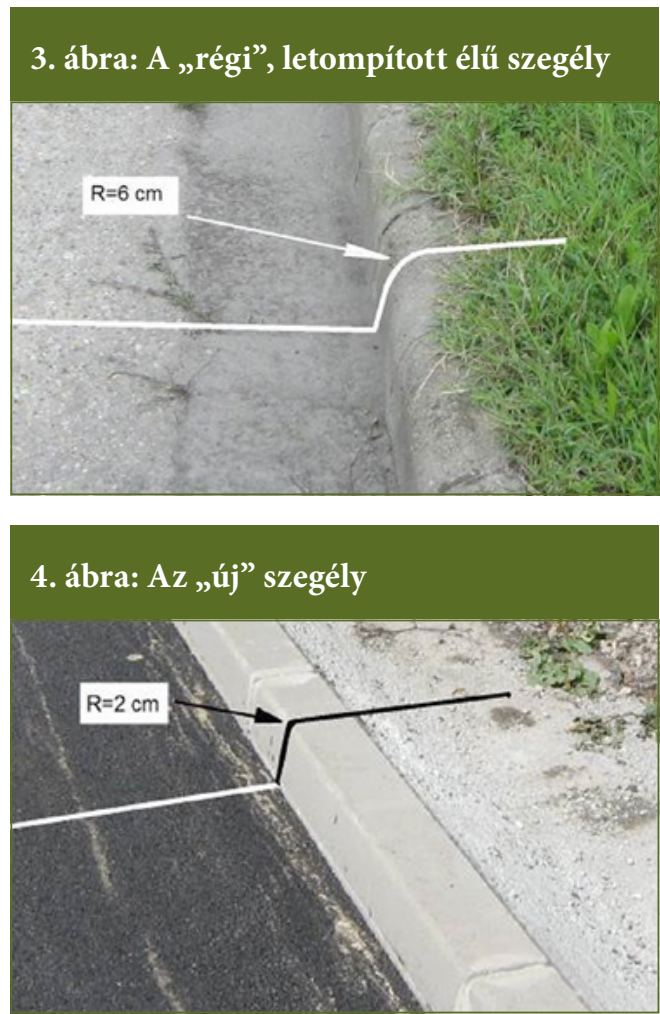


\section{Közúti közlekedés}

A gyalogosok ma jobb „viszonyban” vannak a kiemelt útszegéllyel, mint korábban. Ez elsősorban az utcasarki szegélysüllyesztéseknek köszönhető. Kérdés azonban, hogy egy csomóponti járdasüllyesztéskor törődünk-e azzal, hogy emiatt ne alakuljon ki túl széles folyásfelület a gyalogosok előtt, keresztben?

A kiemelt szegély és a polgárosodás. Nem szabad megfeledkezni még egy nagyon fontos összefüggés elemzéséről, a polgárosodás és a kiemelt szegély viszonyáról. Ezt azonban tágabb értelemben, a polgárosodás és a közterület-kultúra címen lenne indokolt kutatni. A kiemelt szegély azért kiemelt jelentőségü, mert utólagos beépités esetén:

1. eltünnek a sáros padkák és parkolók,

2. megjelennek a (szegély által védett) zöldfelületek,

3. lassacskán átépítik a mélyfekvésü elöntéses és víztócsás járdákat is,

4. a gyalogos járófelület magasabbra kerül az útpálya szintjénél, ami által a gyalogos a belterületi közterület első számú szereplöjének és viszonylagosan nagyobb biztonságban levőnek tarthatja magát.

Uj épitésü utca esetében ez egy ütemben is megvalósítható.

\subsubsection{A természeti környezet}

A kiemelt útszegély és az éghajlatváltozás. Ez utóbbi természeti folyamat úgy kerül a képbe, hogy a miatta egyre hevesebbé váló záporok nyomán a meredekebb utcákban alkalmasint az egész útpályát ellepve folyik le a víz. Sőt, megesik, hogy az utca teljes szélességében zúg le az áradat. Ilyenkor a helyileg érintettek között természetes reakcióként merül fel pl. az útszegélyek valamiféle megemelése a házakpincék elöntése ellen - ez azonban a lejtős út alján csak növelné a bajt. (Ezért kell a homorú keresztmetszettel kiépített hegyi mélyutakat is mind felülvizsgálni.) Az rendjén való, hogy a küszöböket, a pinceablakokat zápor idején hirtelenjében lezárjuk, eltömjük, de a végleges megoldás a vízlefolyás lassítása, késleltető ciszternák építése és a telkekre eső csapadékvíz tárolása, újrahasznosítása lesz.
Ebben azonban a kiemelt szegélynek nincs közvetlen szerepe.

A kiemelt szegély és a fák. Gyakori az utcai fasorok és a kiemelt szegélyek, ill. burkolatok közötti konfliktus, az említett elemek felnyomása a fa gyökerei által (5. ábra). Ha nem megfelelö fát ültetünk, nem megfelelö mélységre és nem megfelelő méretű szabad földfelülettel, akkor néhány év múlva már látható, hogy csatát vesztünk a burkolatfelnyomó fagyökerekkel szemben. Természetesen a probléma nem ilyen egyszerű, ezért alapos kutatás szükséges a meglevő ismeretek kibővítésére és a „béke megkötésére".

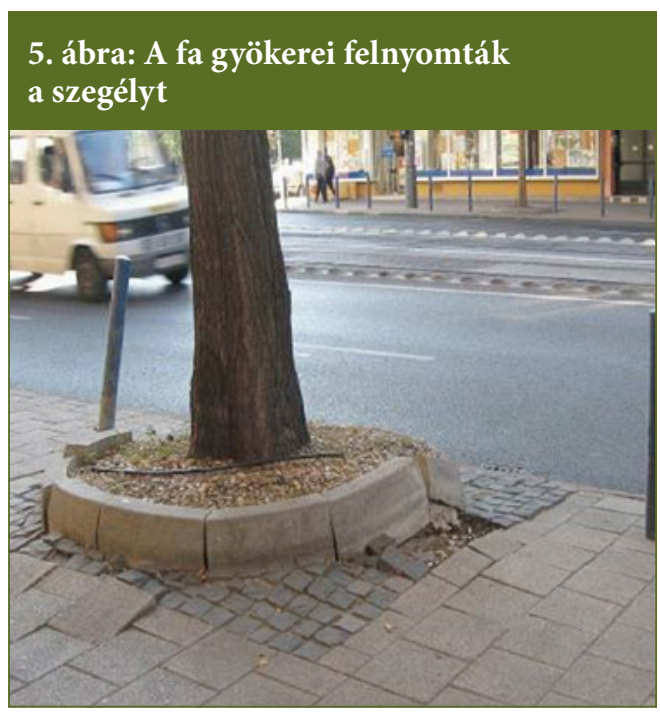

\subsubsection{Az időtényezö}

Az időtényező már fel-felbukkant az előző pontokban, hiszen az egyes környezeti viszszapillantások óhatatlanul folyamatelemzéssé válnak. Lehet azonban az idő szerinti vizsgálatnak is további hozadéka: a kiemelt szegély története újabb összefüggésekre mutathat rá. Miért és mikor jelent meg a városokban ez az elem? Hogyan és miért változott a szegélymagasság az idők folyamán? Mitől függ ma az, hogy melyik útra kerül kiemelt útszegély és melyikre nem? Eltünhet-e a szegély és mikor, legalábbis helyenként, átveheti-e a szerepét egy korlát, egy felfestett színes vonal, egy prizmasor, vagy LED-es lámpasor vagy valami más? 


\section{Közúti közlekedés}

\subsubsection{A „hely”-tényezö}

$\mathrm{Az}$ előző pontban vázolt kérdéseket szinte mindenütt kiegészíthetnénk a „hely”-re történő rákérdezéssel is. A hely azonban sokrétü: a világrészektől az egyes országokon át a különböző településekig, a polgárias belvárosoktól az árkos vízelvezetésü más településrészekig, falvakig tart. (Ezekre a 2.1.4. pontban már utaltunk.) Nyugaton a belterületi utcák döntő többségét már településtípustól függetlenül kiemelt útszegély határolja (vagy bizonyos helyeken már ismét nem határolja...). Jelzésértékü viszont, hogy míg a régi hazai tsz-telepek útjai kiemelt szegély nélkül épültek, az 1990 utáni ipari parkok szinte mindegyike kiemelt szegéllyel üzemel. Ezért aztán a 2.1.3. pontban vázolt polgárosodás- és a közterületkultúrakutatásnak lehetne akár egy olyan fejezete is, hogy telephelyi rend-és munkakultúra. Bár ez látszólag távol áll a kiemelt útszegélytől, de példa arra, hogy egy látszólag kis tényező is hogyan vezethet el egy fontos kutatási feladathoz.

\subsection{Második téma: az útkiépítettség elem- zése}

Az útkiépítettségen még a közutas szakmában is sokan a szélesebb útpályát, jó minőségü útfelszínt, széles padkát és jó vízelvezetést értenek. A bizonytalan tartalom miatt a fogalmat viszonylag ritkán használják. Nézzük meg, hogy nem kellene-e ezen a téren rendet teremtenünk?

\subsubsection{Az út-szakmai környezet}

Az útkiépitettség mértéke egy viszonyszám, egy \%-os érték, amely megmutatja, hogy ez adott útcsoporton belül mennyi a szilárd burkolattal ellátott utak hossz-aránya?

Ha csak a „szilárd” burkolat tartozik ide, akkor a kavicsolt-murvázott, darált aszfalttal ellátott útfelületek és a vizes makadám nem számítanak burkolatnak. Ne is számítsanak, de legyen valamiféle javított talajút kategória is, mert több önkormányzatnak egyes belterületi és sok külterületi útjára még jó sokáig nem jut szilárd burkolat, de a felületjavítás- sal mégis tesznek valamit a közösségért. Ezt azért indokolt a megkülönböztetéssel elismerni, mert egy út használhatóságában - kis forgalom esetén - jóval nagyobb az elörelépés a földút és a kiárkolt-javított talajút között, mint a javított talajút és a szilárd burkolat között [1]! Ez föleg a szántóterületi utaknál fontos tényező. Ezt a problémacsomagot széleskörűen meg kell vitatni és új kutatásokat indítani!

\subsubsection{A tágabb müszaki-gazdasági környezet}

Az útkiépitettség müszaki-gazdasági jelentősége. A mai felgyorsult, motorizált korunkban szinte minden polgárnak létfeltétel, hogy a lakása, munkahelye szilárd burkolatú úton legyen megközelíthető. Bár a belterületi önkormányzati utakból a nyilvántartás szerint még $15975 \mathrm{~km}$ burkolatlan (6. ábra), ezek nagy része valószínüleg különböző színvonalú javitott talajút. A helyszíni tapasztalatok szerint a kiskertes övezetek és a volt zártkertek, szőlőhegyek ma is müvelt részeinek útjai is általában legalább javított talajutak. Legkedvezőtlenebb helyzetben a mezőgazdasági növénytermesztés van, mert a szántóterületeket feltáró önkormányzati utak 95\%-a burkolatlan. Ezeken az utakon nagyobb a fajlagos üzemanyag- és üzemidö-felhasználás, nőnek a gépkarbantartási és javítási költségek, nagyobbak a szállított termények szóródási és rongálódási veszteségei, napokkal lekéshetők a kritikus munkafázisok optimális időpontjai, és persze utánpótlást biztosítanak a burkolt utakra történő sárfelhordásnak stb. [2]. Egy vázlatos számítás szerint, csak magánál a terménybetakarításnál, évente mintegy 20 milliárd Ft többletköltség - vagy néven is nevezhetnénk, hogy veszteség - keletkezik ezekből, és ezt minden évben elszenvedjük. Emiatt a magyar gazda eleve versenyhátrányban van az európai piacon a 90\%-ban burkolt mezei utakon járó nyugati vetélytársával szemben, és a hazai piacon mi is megfizetjük a rossz utak miatti mezőgazdasági többletköltségeket. A magyar társadalom és gazdaság egyelöre tudomásul veszi ezeket a veszteségeket, mert úgy gondolja, hogy ma még nincs elég ereje a hátrány felszámolásához. 


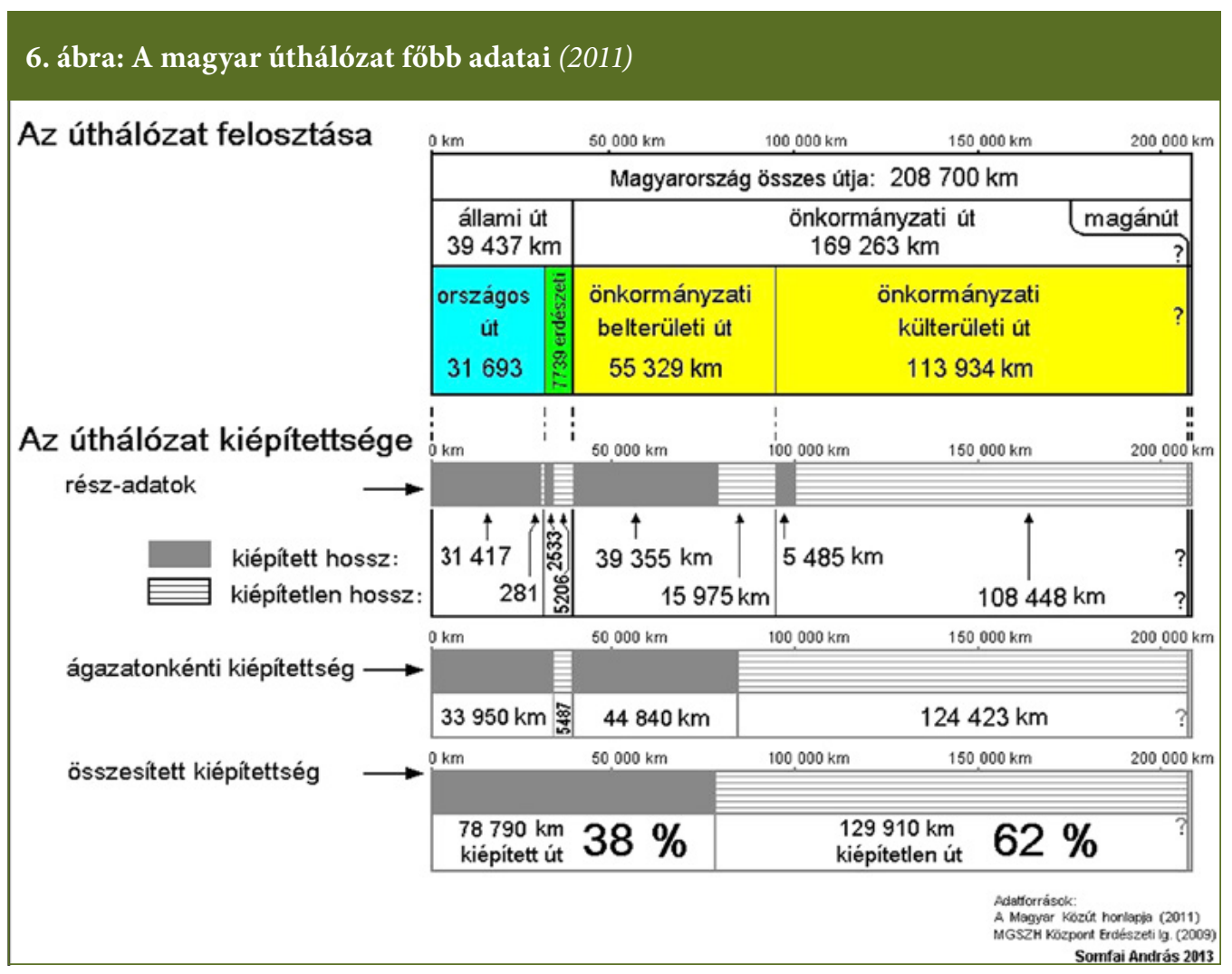

\subsubsection{A társadalmi környezet}

Az útkiépités és a „vidéki” társadalom szervezése. Település- és tájtörténeti tapasztalat, hogy általában a szomszédos településeket összekötő földutak lettek a szántóterületek fö megközelítő útvonalai is. Ezek egy része aztán állami útként kiépült, a többi viszont nagyrészt földút maradt. A külterületi útkiépítés megrekedése azonban nemcsak a mezőgazdaságot, hanem a vidéki társadalom kapcsolati-mozgási lehetőségeit is korlátozta. Pontosabban: a ki nem épült falu-szomszédsági utak „civil” forgalma a személyautóra váltással párhuzamosan elsorvadt, mert áttevődött a hosszabb, de kiépített kerülőutakra. A vidéki társadalom tagjai ugyan óhajtanák a településközi úthálózat továbbfejlesztését, de nincs nagyléptékü országos program, így aztán nem is reménykednek, mert az útépítés drága. Ezért igazgatási, ellátási-szolgáltatási, buszközlekedési, munkahelyi-munkaválla- lási, idegenforgalmi, társadalom-kapcsolati, stb. szempontokból a kistérségek társadalmának „üzemelése” is torz, mert a központi település vertikális függelmében élnek, kevés horizontális kapcsolattal. Az állami mellékúthálózat ugyanis a hierarchikus államszervezés igényeit szolgálja. A „faluközi” utak kiépítése elvezethet a policentrikus vidékszervezéshez is (7. ábra). Ebben az együttmüködési rendszerben az egyes települések - adottságaiktól és tehetségüktől függően - mikrotérségi központ szerepet is betölthetnek. Ki ebben, ki abban vagy akár több témakörben, és az ellátás, ill. az életvitel kedvezőbbé válik. A vidéki társadalom és a mezőgazdaság ezen kapcsolat- és helyzetjavulásának anyagi mérlegét azonban össztársadalmi szinten indokolt megvonni és szükséges kutatni. Nem forgalomterhelési értékekkel, mert azok csökkennek, hanem tanultabb, mozgékonyabb polgárokkal, exportképesebb mezőgazdasággal. 


\section{Közúti közlekedés}

\section{7. ábra: A központ-vezérlésü és a policentrikus vidékszervezési sémák}

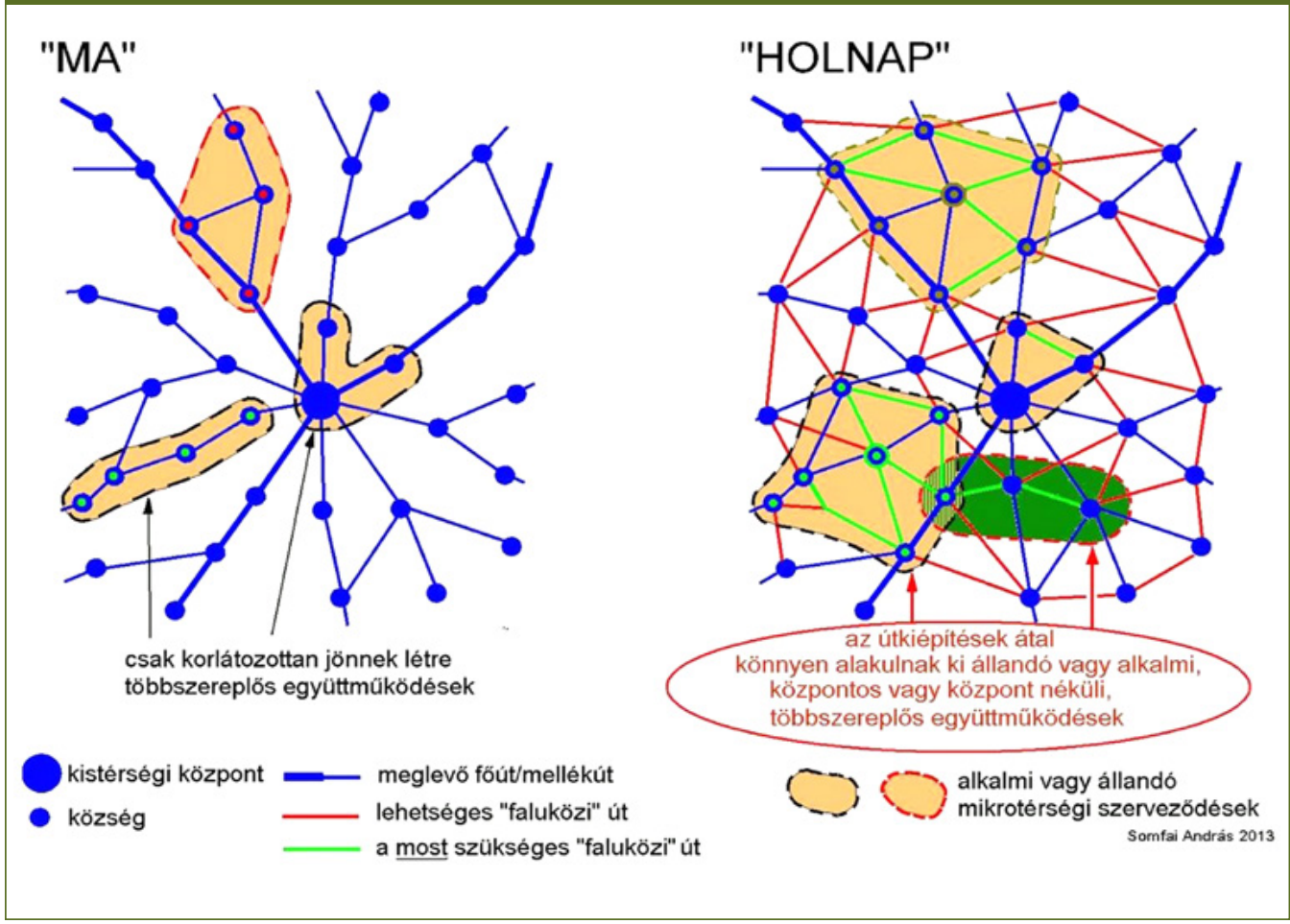

\subsubsection{A természeti környezet}

$A z$ útkiépitettség és a természeti környezet megterhelése. A különbözö rangú és forgalmú utak jelentősen eltérő mértékben és távolságig terhelik meg mind a belterületi, mind pedig a külterületi környezetüket. Ennek ellenére kialakult a „helytől távol élő” társadalom bizonyos csoportjaiban egy általános útkiépítés-ellenző hangulat és a kisforgalmú utak kiépítési szándékát is támadják. Nincs módszer arra, hogy a helyben élők előterjesszék saját komplex környezeti-gazdasági mérlegüket, a mezőgazdasági ágazat pedig még nem ismerte fel ebbéli kulcsszerepét. Egy forgalmas mezőgazdasági földút faluközi útként történő kiépítése egyszer azért került le a napirendről, mert „az út mellett levő nagy fán élő ritka fajú madarat zavarná a forgalom". A témát tehát egy alapos elemzés után indokolt újrafogalmazni.

\subsubsection{Az időtényezö}

Magyarország mai útkiépítettségi aránya 38\% (8. ábra). Nézzük meg, hogy jutottunk el ide!

A hazai útkiépités fejlődése. A történelmi dokumentumokból megállapították, hogy Napóleon korában a mai Magyarország területén kereken $700 \mathrm{~km}$ kiépített út volt - persze azok ma kavicsolt útnak, legfeljebb rakott alapnak lennének nevezhetők. Ez a kb. 2 ezreléknyi kiépítettség a múlt század húszas éveire kb. 10\%-ra, 1990-re pedig 40\%-ra nőtt (8. ábra). Az 1992-es 42\%-os csúcs után azért esett vissza a kiépitettség aránya, mert a mezögazdasági privatizáció és az épitési telkek tömeges kiparcellázása során sokkal több új (föld-)utat jelöltek ki, mint amennyit kiépitettek. Pedig a korábbiaknál többet építettek! Ez a visszaesés, békeidőben, valószínűleg egyedülálló eset volt a világon. 


\section{8. ábra: A magyar útkiépítettség eddigi alakulása}

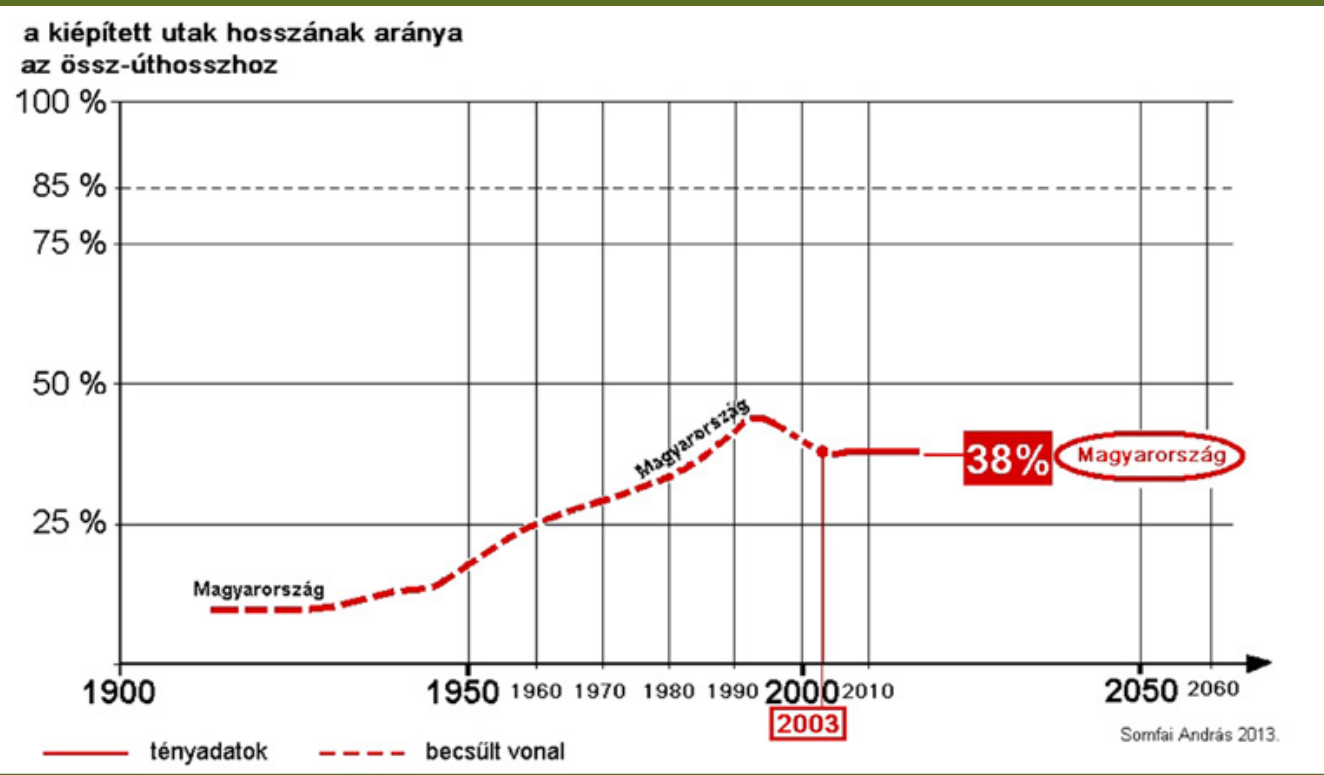

\section{9. ábra: Néhány európai ország útkiépítettségének alakulása és a várható magyar jövőkép}

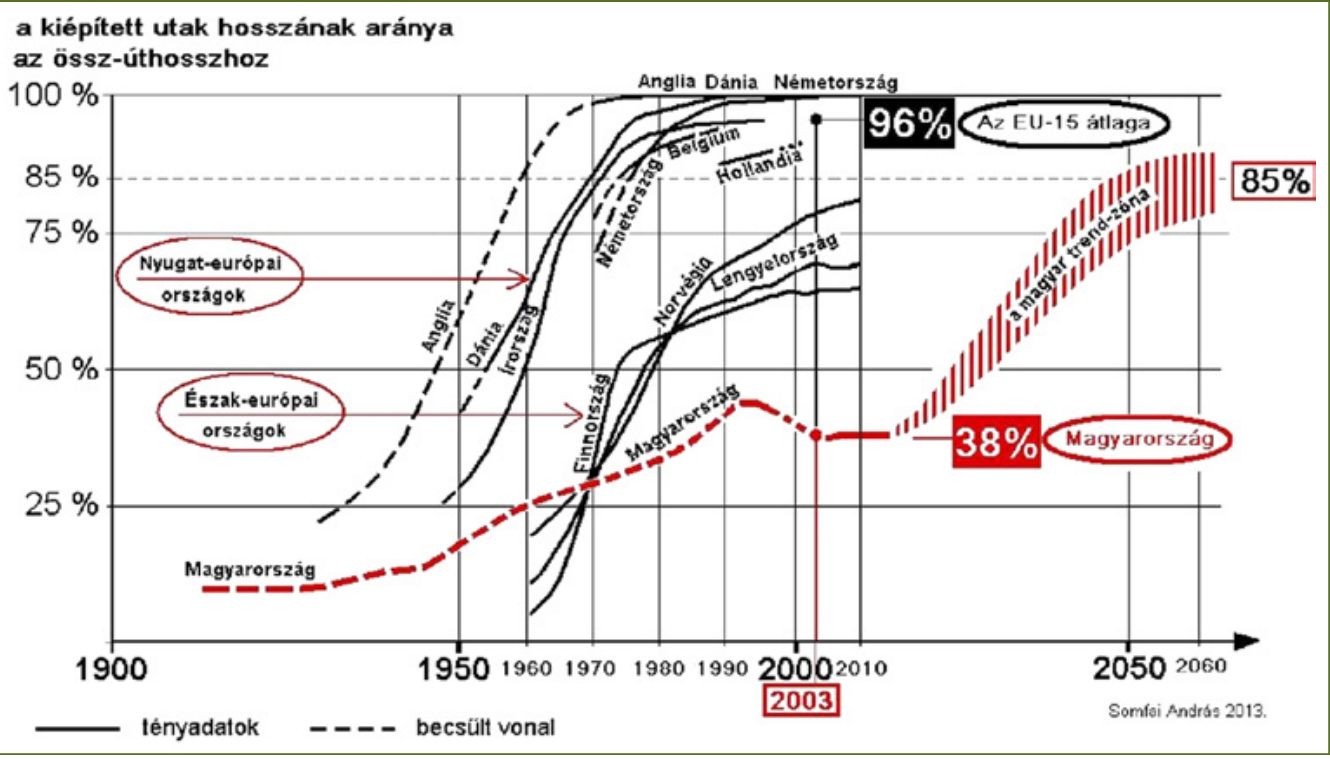

\subsubsection{A „hely”-tényezö}

Összehasonlítás Európa más országaival. Az elözők után kezd igazán érdekessé válni az, hogy hogyan alakultak az európai országok útkiépí- tési grafikonjai? Adatbizonytalanság és nyilvánvaló adathiba miatt csak a 9. ábrán feltüntetett kilenc ország útkiépítési „életvonalát” tudtuk megrajzolni, de már ezek is sok tanulságot közvetítenek. Igazolódott, hogy az útkiépítettség 


\section{Közúti közlekedés}

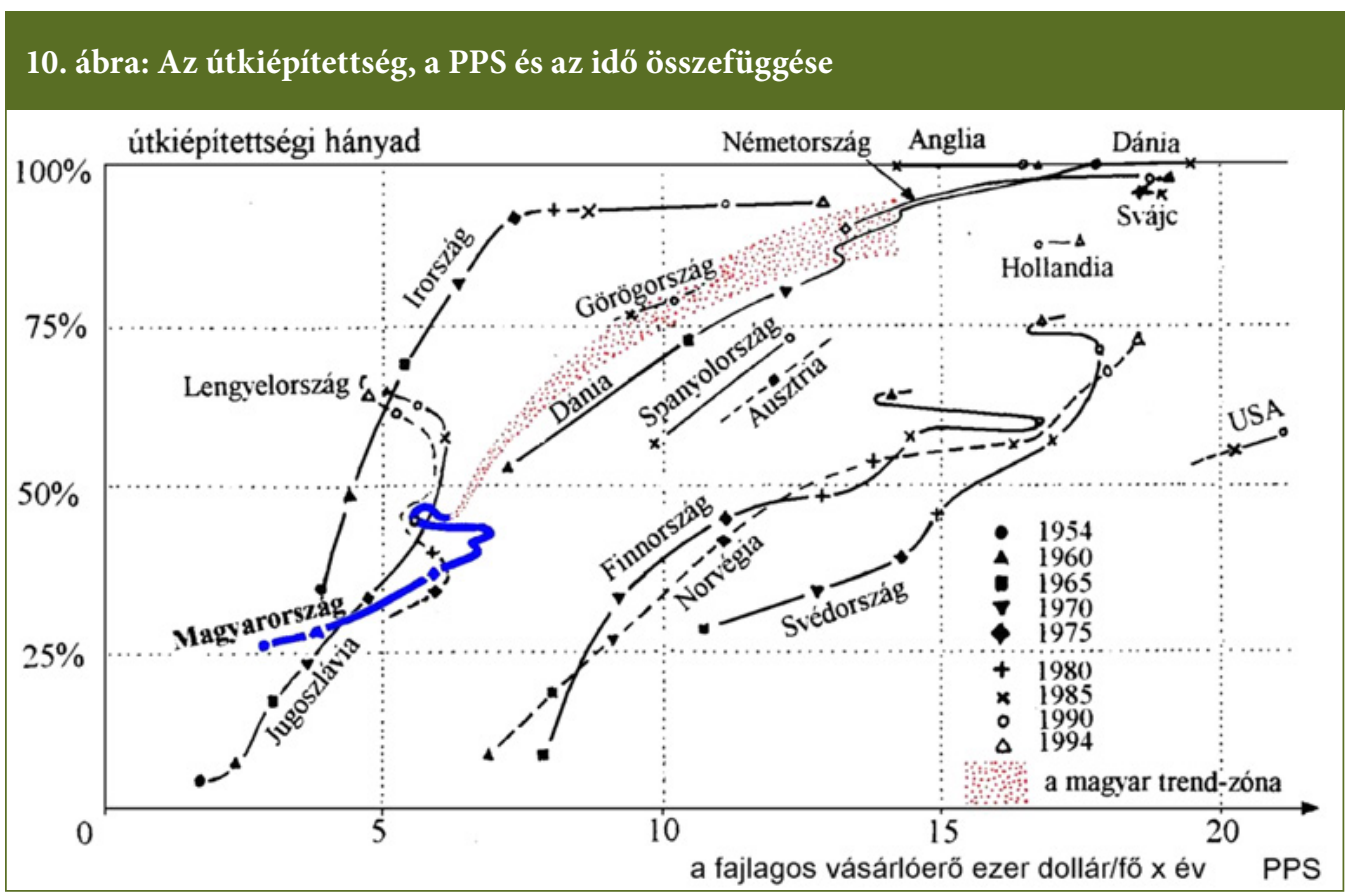

történelmi kategória, amelynek csúcsértéke akár $100 \%$ is lehet, és hogy a magyar útkiépítettség-visszaesés a rendszerváltáshoz köthető, kivételes jelenség. Az útkiépítettségnek a gazdaság erejével való korrelációjára pedig a 10. ábra mutat rá, miszerint a fajlagos nemzeti vásárlóerő növekedése az útkiépitettség emelkedésével jár. Sőt, mint néhány ország vonala mutatja, még átmenetileg visszaeső fajlagos nemzeti jövedelem mellett is nőtt az útkiépítési arány.

A tendenciákból azt a következtetést vontuk le, hogy a magyar útkiépítettség is egy telitettségi érték felé tart, amely valószínüleg nem lesz 100\%, legfeljebb 85-90\%, a telítődés ideje pedig 40-50 év múlva következhet be. Mivel ez a jövőkép soktényezős gazdasági, müszaki, politikai és demográfiai feltételezésen alapul, az út-közlekedési szakma legnagyobb hatású kutatása ezeknek az értékeknek a pontositása kell, hogy legyen.

\subsection{A harmadik téma: a közterület-szabá- lyozás}

A közterület-szabályozás gyüjtőfogalom, amely magában foglalja a közterület-lehatá- rolást, valamint a térszinti, a térszint alatti és a térszint feletti közterületi elemek közösségi érdekű, egymással összehangolt, vízszintes és magassági elrendezési tevékenységét. Összetett, többszakmás cselekvéssorozat. Melyek itt a szorító feladatok?

\subsubsection{Az út-szakmai környezet}

Az út-szakma és a közterület viszonya. A közterület fogalma - az 1997. évi építési törvény [3] szerint - „közhasználatra szolgáló minden olyan állami vagy önkormányzati tulajdonban álló földterület, amelyet az ingatlan-nyilvántartás ekként tart nyilván”. Az út-szakma ennél szűkebb fogalomként használja a közút kifejezést: a KRESZ [4] szerint a közút „a gyalogosok és a közúti járművek közlekedésére szolgáló közterület”. Mivel a 314/2012. sz. kormányrendelet 8 . sz. melléklete - közterület-alakítási terv (KAT) néven - a közterülethez köti azt a tevékenységet, amelynek a továbbfejlesztésére szeretnénk a figyelmet felhívni, most mi is ezt a lehatárolást használjuk. 


\section{1. ábra: A közterületen belül, ill. annak határán elhelyezhető elemek}

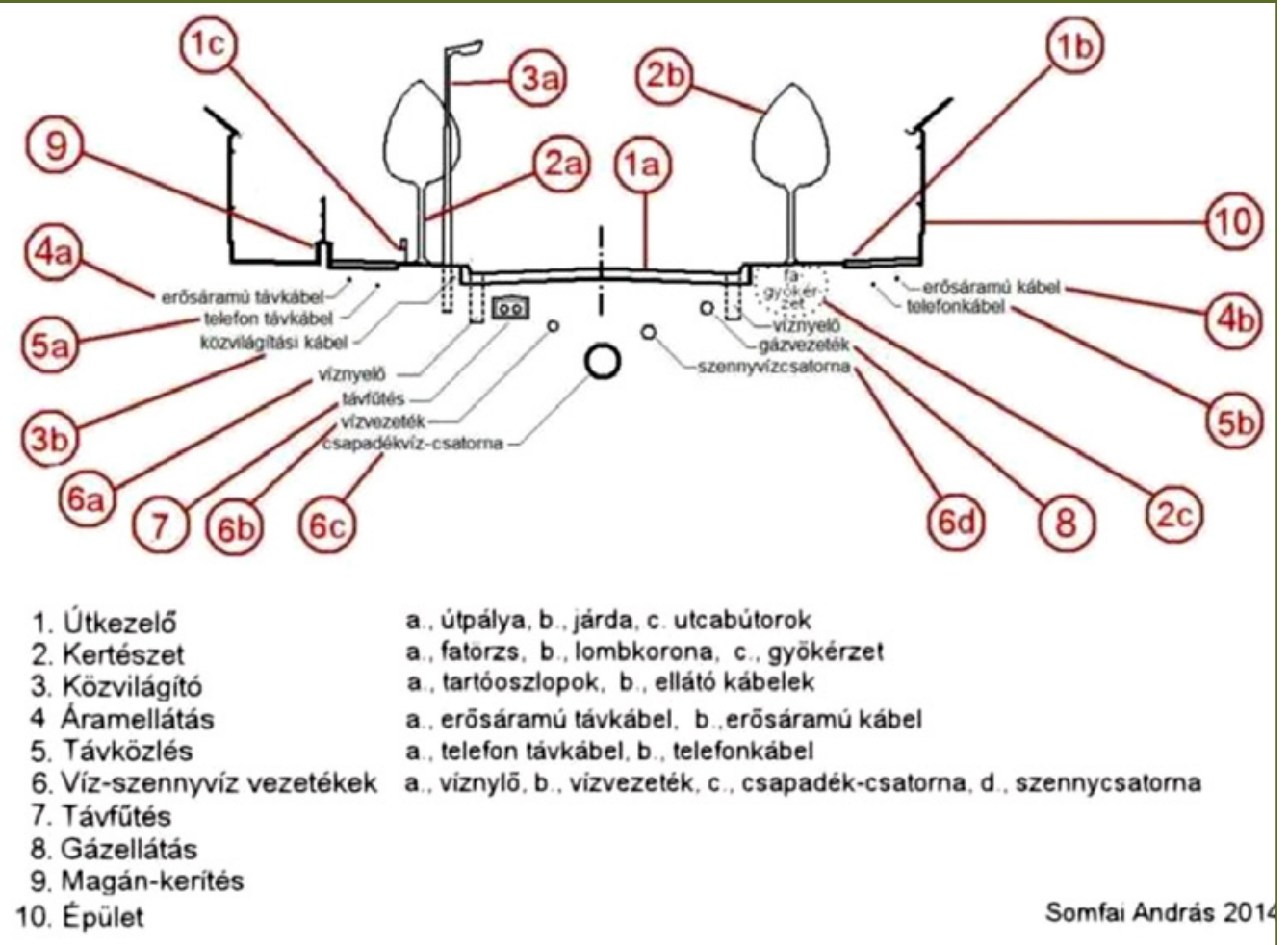

\subsubsection{A tágabb müszaki-gazdasági környezet}

A közmü-szakági szabályozások viszonyai. A közterületeken nyolcféle közművezetéket különböztetünk meg, a közterület határán pedig érintett lehet a kapcsolódó telken levő épület vagy kerítés (11. ábra).

Egy átlagos utcában nincs ennyi közmủ és más építmény. Az elosztóvezetéken kívül néhol viszont előfordul egy-egy nagyobb átmérőjü gerincvezeték. Összesítve: tízféle érdek, szabály és rendelettömeg szabja meg a térszinti, a térszint alatti - és az ezzel összefüggő térszint feletti - helyszínrajzi és magassági elrendezést.

A szakági terveket az egyes tervezők a saját szakmai elöírásaik szerint dolgozzák ki. A közterületen belüli elhelyezésre, a vezetéknek a többitől, a fáktól és az épületektől betartandó legkisebb távolságára is vannak szabályok
[5], amelyek a fák és a burkolatok távolságára vonatkozóan elnagyoltak. Régebben még a közmürend is szabott volt (a 11. ábrán ez a „klasszikus”, V-alakú közműrend látható), de ezt a kötelezést kb. 50 éve el kellett törölni, a közművek és a települések újabb fejlesztési igényei miatt. A „szabad” közmüelhelyezés sokszor vezetett az utcakeresztmetszet gazdaságtalan használatára, egy újabb közmüvezeték jelentkezése esetén pedig kényszerü vezetékáthelyezésekre, hogy a kisebb anomáliákat ne is említsük. A teljes közmüfektetési elöírásrendszert újra kell fogalmazni, a közterületi koordináció szabályait is meg kell alkotni, tekintettel a modern vezetékanyagokra és a közös gazdaságosság elvére is. Már csak azért is, mert a ma is érvényes vezeték-védőtávolságok azon alapulnak, hogy a szomszédos vezetékek munkaárkai között legalább $50 \mathrm{~cm}$ zavartalan földmag maradjon, ami ma már elavult feltétel. Olyannyira újragondolandók a méretek, hogy 


\section{Közúti közlekedés}

amikor a 90-es években a települések vezetékes gázzal való ellátása politikai paranccsá vált, az elhelyezést nem a szabványok, hanem a „józan ész” és a „szerelési távolság” nevű szabályok vezérelték a kritikus szakaszokon. Az elöírások megalkotásához ezeket, és persze következményeiket is ki kell elemezni. Ebben a munkában az út-közlekedési szakmának is részt kell vennie, sőt a közterületi koordinátor szerepet is el kell vállalnia!

A térszint-magassági szabályozás helyzete. Közterületeink hossz- és keresztszelvényi kialakítása - Budapestet kivéve - sajnos többnyire meglehetősen kötődik a terephez, ha hullámzó vagy nagy a keresztlejtése, akkor is, de sokszor még mély fekvés esetén is. Budapest óriási előnye az, hogy a Fővárosi Közmunkatanács megalakításáról szóló 1870. évi $\mathrm{X}$. törvény az FKT feladatául szabta az „utak és utczák irányzatának és niveaujának” meghatározását, és ez a folytatólagos tevékenység tette, teszi a magyar fővárost térszinti értelemben is rendezetté. Vidéken ennek hiánya esetenként meredek kapubejárókat, lépcsős járdákat, telekre folyó közterületi csapadékvizet, belvízzel elöntött utcákat, stb. eredményezett. (Még az is előfordult, hogy egy új út építésénél egy nyomóvezetéket a terephullámhoz igazodva fektettek le, amelyet aztán az útépítés előtt el kellett bontani és mélyebb szinten újra megépíteni.) A hibákra aztán még a koldusszegény(ségben tartott) közúti ágazat is szó szerint rátett: a nyíltárkos utak járófelületének rátöltögetése, aszfaltszőnyegezése és így a pályaszint fokozatos emelése mellett a járdákat mélyen hagyta. Ezzel rontotta a járda vízelvezetési esélyeit és a rajtuk közlekedő gyalogosok méltóság- és biztonságérzetét (12. ábra). A 3.3.1. pontban már említett közterület-alakítási terv (KAT) arra kötelezi a tervezőt, hogy az új utcanyitásoknál határozza meg mind az útpálya, mind pedig a járdatövek (kerítéstövek) szintjeit. Szükség lenne azonban a tervfajta egyszerübb, olcsóbb változatának kidolgozására, hogy legyen mód a szabályozást valamennyi közterületre elkészíteni, hogy a belterület többi részén is vezérelje a szinthibák szívós, fokozatos javítását. Mert mint láthattuk, a meglevő utcákban is van bőven javítani való.

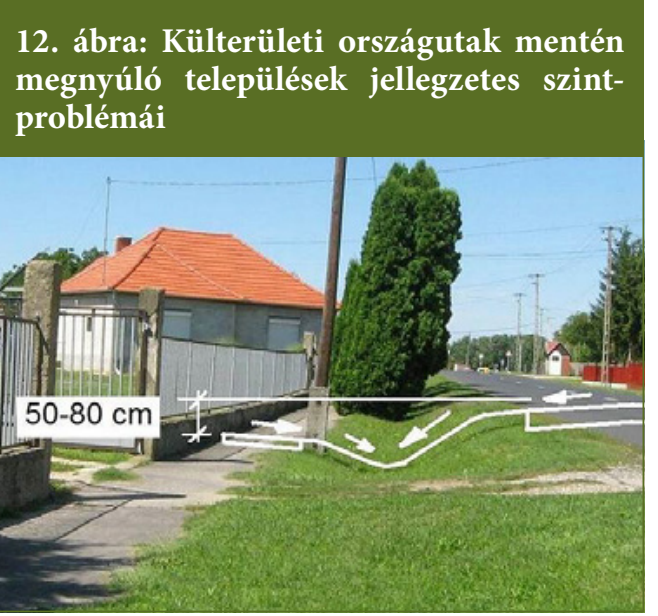

Árok, zárt csatorna vagy valami más? Magyarországon a belterületi utcákban $\mathrm{kb}$. 90\%-ban nyíltárkos a csapadékvíz-elvezetés, ugyanakkor Nyugat-Európát járva, még a kis falvakban is alig találunk a belterületen nyílt árkot. Nálunk a városok sem sietnek a külső városrészekben csapadékvíz-csatornázni, a várossá vált egykori falvak pedig még a városközpontjukban sem. Ma elsősorban természetesen gazdasági kérdés a csapadékvíz-csatornázás, de nincs világos jövőképe erről még a műszaki szakembereknek, de a társadalomnak sem. Sajnálatos, hogy a Lechner Tudásközpont által 2017-ben kiadott Településképi Arculati Kézikönyv mintaanyaga még csak meg sem említi sem a közterület-szabályozást, sem az éghajlatváltozás-árok-csatorna problémakört. (Ebből is látszik, hogy menynyire hiányoznak nálunk a jól képzett települési fömérnökök.) Ha a település arculatának legalább a felét alkotó közterület látványa és gyülekező problémái az építészet szintjén ennyire hangsúly nélkül maradnak, akkor nem tudunk közösen felkészülni a feladatok koordinált megoldására. Már csak azért sem, mert az éghajlatváltozás következményei, valamint a közterülettel, a csapadékvízzel és a csőkeresztmetszetekkel történő gazdálkodás igénye átfogalmaztatja az eddigi szemléletünket és terveinket, valamint a közterületszabályozás módszertanát is. Sokágú, nagy költségü és több szakmát érintő feladatról van szó, amelynek előkészitő kutatásait mielőbb meg kell kezdeni. 


\section{Közúti közlekedés}

\section{3. ábra: A magyar társadalom két évszázados átalakulásának vázlata}

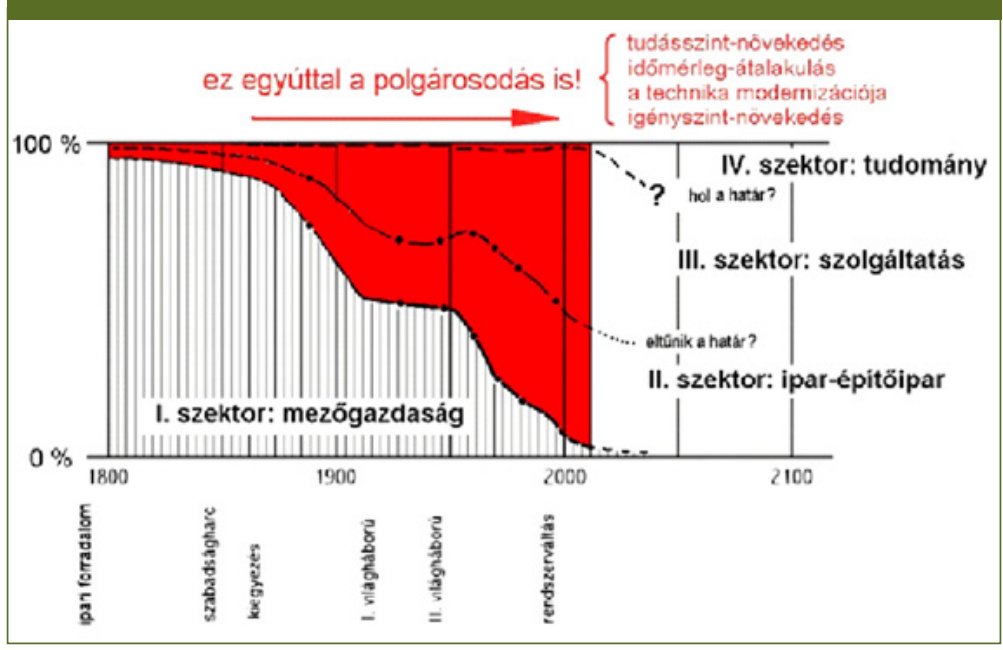

kolót, a mélyen fekvő keskeny járda helyett az útpálya szintje fölé emelt "kétszemélyes" és tócsamentes járdát, stb. igényel. (14. ábra). Ez pedig így, együtt, a lakos és az utca polgárosodásának folyamata, lélekadás a közterületnek, amelyet bele kell kalkulálni a terveinkbe akkor is, ha még kéthárom évtizedig eltart a megvalósítása. $\mathrm{Ne}$ város legyen a faluból, hanem városias település, ami elsősorban a közterületek minőségi fejlesztésében nyilvá-

\subsubsection{A társadalmi környezet}

A társadalmi „megrendelés” kérdése. A közterület-szabályozással és az éghajlatváltozás település-müszaki következményeivel $\mathrm{mi}$ müszakiak sem foglalkozunk a súlyának és sürgösségének megfelelően. Nem küldünk jelzéseket a társadalom és a politika felé, pedig a közterület-szabályozásnak kidolgozott tematikája van, az éghajlatváltozásnak pedig jó a sajtója, tehát lenne mihez kapcsolódni a tennivalók felsorolásával. Így aztán nem is várhatjuk a társadalom „megrendelését”, ehhez előbb nekünk kell lépnünk, megfelelő meggyőző eszközzel a tarsolyunkban.

Az utca „polgárositása”. Nagy átalakulási folyamatban van a hazai társadalom, azon belül is különösen a vidék társadalma: a 13. ábra tanúsága szerint a fél évszázaddal ezelőtti 50\%-ról mára kb. 4\%-ra esett vissza a mezőgazdasági népesség aránya. (Itt vannak vitatott elnevezések és vitatott számok, amelyek miatt a társadalomtudományhoz kellene fordulnunk.)

Megváltozott a falvak lakosainak szektorösszetétele, időmérlege, érdeklődési köre, a környezete iránti igényessége, stb. (Városokban is van ilyen folyamat, de jóval kisebb léptékben.) A falusi polgár a saját településén is rendezettebb közterületeket, a sáros útpadka helyett burkolt par- nuljon meg, ne pedig az emeletszám növelésében. A széles olvasóközönség tájékoztatására, a többször meg-megakadó magyar polgárosodás folyamatának újabb fellendítésére, közös ismeretterjesztő könyvet is írhatnának a müszaki- és társadalomtudományok jeles reprezentánsai.

\subsubsection{A természeti környezet}

A külterületi táj befolyásoló hatása a belterületi közterület-szabályozásra. A gyakorlatban szélsőséges példák láthatók a meredek terepen nyitott új utcában a terepnek szinte teljes megtartására, de a vízszintesre gyalulására is. Hogyan oldották meg magasságilag a telekcsatlakozásokat? Mi a szabályozási terv készítöjének feladata és felelössége ilyen esetben? Ha a fejlesztési terep belvizes, akkor mik a lehetséges megoldási módok? Vizsgálni kellene nagy számú, különböző természeti, vízrajzi, talajtani, stb. helyzetben megvalósult utcákat, beépítéseket, hogy a jó és kevésbé jó megoldásoknak - a Települési Arculati Kézikönyvhöz hasonló tervezési segédletbe gyüjtésével elö lehessen segíteni a „kézfogást” a települések és a táj között.

\subsubsection{Az időtényezö}

A közterület-szabályozásban - és ezzel szoros összefüggésben a települési csapadékvíz-gazdálkodásban is - az elöretekintésünk idötáv- 


\section{Közúti közlekedés}

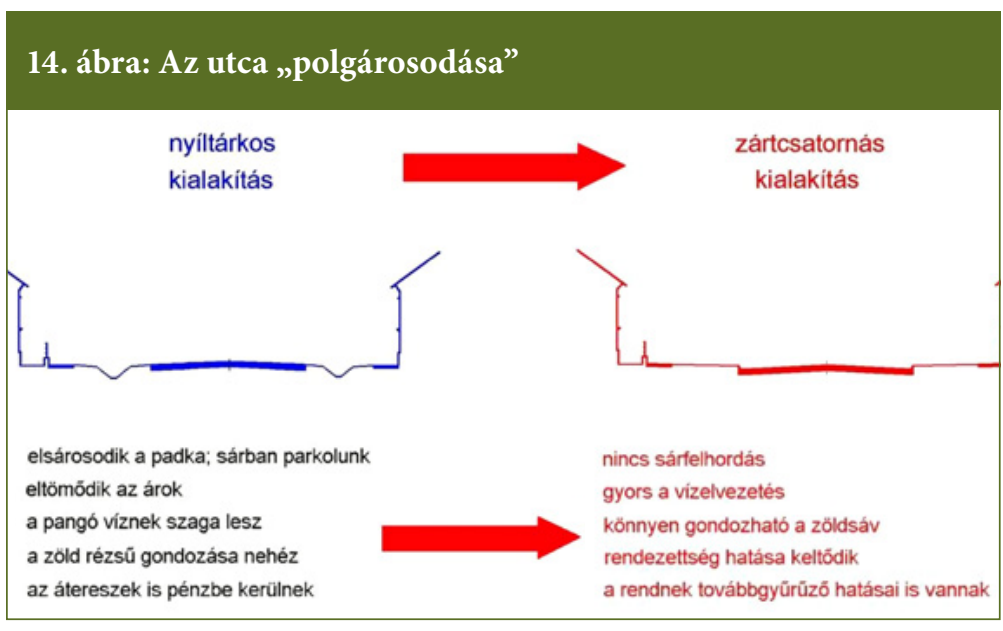

adaptálni. Ennek a problémának azonban nagyon sokféle olvasata van, amiért fiatal mérnökök, cserediákok, doktoranduszok tucatjait kellene Nyugat-Európa különböző országaiba - de akár délre, északra és keletre is - küldeni, hogy a müködő gyakorlatot - a társadalmi, gazdasági és politikai hátterével együtt megismerjék, és ezek tanulságai alapján le-

latának és komplexségének kritikus esetekben igen nagy súlya lesz.

Százötven év tanulságai. Rövidesen másfél évszázada lesz, hogy a budapesti Fővárosi Közmunkák Tanácsa megkezdte müködését. Célszerű lenne az FKT és utódszervezetei müködésének szakmai áttekintése a meglevő irodalom felhasználásával, és a mának megfogalmazható általános és egyedi üzeneteik közreadásával. A könyvnek készülhetne egy népszerü, irodalmi stílusú változata is, a nagyközönség tájékoztatására, a reálértelmiség népszerüsítésére. Persze közterület-szabályozási tanulságokat a nem budapesti rendezési tervekből is össze lehetne gyüjteni.

Fontossága miatt itt is megismételjük a 3.3.2. pontban leírtakat: Az éghajlatváltozással és a csapadékvíz-gazdálkodással kapcsolatos elökészitő kutatásokat mielőbb meg kell kezdeni!

\subsubsection{A „hely”-tényezö}

Egyes nyugati országok gyakorlatának tanulmányozása. Mind a közterület-szabályozásban, mind a csapadékvíz-gazdálkodásban új utakat kell járnunk Magyarországon. Ilyenkor jól jöhet minden hazai és külföldi tanács vagy tapasztalat. Mivel a németek például a szürkevíz-hasznosításukkal a víztakarékosságnak már ma is nagyon magas szintjén járnak, e témakörben is fontos lenne a német gyakorlatot tanulmányozni és a magyar körülményekre hessen a hazai munkamódszert kifejleszteni, néhány buktatót elkerülni.

\section{KONKLÚZIÓ}

Az útépítés világszerte felfelé ívelő pályán halad. Nagy iránta Magyarországon is a társadalom és a gazdaság igénye, de óriási a pénzigénye. Ez nagy felelősséget ró ránk.

Szakmánk folyamatos fejlődésben van, de a számunkra az igényeket megfogalmazó társszakterületek maguk is folyamatos átalakulásban vannak. Emiatt permanens, kölcsönös jövőkép-finomítási folyamatra számíthatunk.

Kérdés, hogy elegendő-e az, hogy egy probléma csak akkor váljon kutatási témává, amikor rendezetlensége átlépi a társadalom egyes csoportjainak ingerküszöbét? Kérdés az is, hogy nem kerüli-e el figyelmünket valamely adat, adatpár vagy funkció, amely napi cselekvéseinket is befolyásolná?

A veszély fennáll. Kíséreljük meg ezt azzal csökkenteni, hogy a szakmát és fö külső környezeti tényezőit, valamint az időt és a teret egy hat- vagy többdimenziós mátrixba foglalva, elemezzük ki valamennyi lehetséges, hat- vagy több összetevős csomópontját. A keresés tétje az, hogy az így létrejövő tématárban nem tünik-e fel - a már megoldott, ill. az értelmetlen problémacímek között - eddig még nem vizsgált, de vizsgálatra mindenképpen 


\section{Közúti közlekedés}

érdemes probléma, összefüggés, feladat vagy tennivaló? Ezek jelenthetnék ugyanis a jövő kutatási kínálatának gerincét. A fogalmaknak a mátrix által történő kényszertársítása épp a rutin-alapú logika bizonyos fokú mellőzése révén hozhat össze új feladatokat. A kutatás kiszolgálására és a tudás terjesztésére ma már elegendően nagy teljesítőképességü informatikai eszközök kínálkoznak, tehát elméleti és gyakorlati szakemberek százai kapcsolódhatnának be a munkába.

Természetesen ez a bekereséses módszer sem talál meg minden új feladatot, és nem nélkülözheti a gondolkodó embert sem. A csomópontok közötti tallózás pedig bármikor felszínre hozhat egy-egy új gondolatot.

A problémakeresés mátrixos elvét ajánljuk minden szakág figyelmébe. Az út-szakmai körre való szűkítés csak a kísérlet áttekinthetősége érdekében történt. A módszert természetesen még tovább kell csiszolni, és meg kell célozni a nagyobb léptékủ hasznosíthatóságát is.

\section{FELHASZNÁLT IRODALOM}

[1] A javasolt harmadik útkategória hiányát mutatja a MK honlapján levő táblázat, amely elérhető a „Rólunk / Közérdekű adatok / Országos Közúti Adatbank / Önkormányzati utak adatai / kiépített-kiépítetlen 2017 címsor alatt.

[2] Somfai András: Sokba kerül a zötykölődés MEZÖHÍR, 2012/1. sz. 139-142. p.

[3] Az 1997. évi LXXVIII. törvény az épített környezet alakításáról és védelméről, 2\$. 13.p

[4] A közúti közlekedés szabályozásáról szóló 1/1975. KPM-BM együttes rendelet, 1.sz. függelék, 1/a. pont

[5] MSZ 7457/2:80 és MSZ7457/3:80 szabvány: Közmü- és egyéb vezetékek elrendezése közterületen

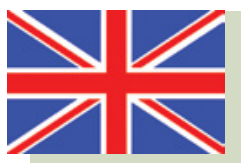

\section{Special forward-looking tasks in the world of roads}

Road construction is on an uphill track worldwide. There is great demand for it in Hungary from both the society's and the economy's side, but it requires huge financial resources. Overall, this is a great responsibility for us.

Our profession is constantly evolving, but the co-disciplines that shape our needs are in constant transformation. Therefore, we can expect a permanent, mutual vision refinement process.

The question is, whether it is enough that a problem only becomes a research topic when its disorder reaches the stimulus threshold of certain groups of society? Another question is whether we might overlook any data, data pairs or functions that would affect our daily actions.

The danger exists. Let's try to reduce this by analyzing all possible nodes of six or more components, by incorporating the profession and its main external environmental factors, as well as time and space in a sixdimensional or multi-dimensional matrix.

\section{Besondere zukunftsori- entierte Aufgaben in der Welt der Straßen}

Der Straßenbau befindet sich weltweit in einem Aufwärtstrend. In Ungarn besteht eine große Nachfrage sowohl von der Gesellschaft als auch von der Wirtschaft, aber es erfordert enorme finanzielle Mittel. Das bedeutet insgesamt eine große Verantwortung für uns.

Unsere Branche entwickelt sich ständig weiter, aber die Co-Disziplinen, die unsere Bedürfnisse prägen, verändern sich auch ständig. Daher können wir einen permanenten, gegenseitigen Verfeinerungsprozess hinsichtlich des Ausblicks erwarten.

Die Frage ist, ob es reicht, dass ein Problem erst dann zu einem Forschungsthema wird, wenn seine Entropie die Reizschwelle bestimmter Gesellschaftsgruppen erreicht? Eine andere Frage ist, ob wir möglicherweise Daten, Datenpaare oder Funktionen übersehen, die unser tägliches Handeln beeinflussen könnten. Die Gefahr dafür besteht. Versuchen wir dies zu reduzieren, indem wir die Branche und ihre wichtigsten äußeren Umweltfaktoren sowie Zeit und Raum in eine sechs- oder mehrdimensionale Matrix einfassen und alle möglichen Knoten mit sechs oder mehr Komponenten analysieren. 